\title{
Settlement of the gregarious tube worm Hydroides dianthus (Polychaeta: Serpulidae). I. Gregarious and nongregarious settlement
}

\author{
Robert J. Toonen*, Joseph R. Pawlik \\ Department of Biological Sciences, Center for Marine Science Research, University of North Carolina at Wilmington, \\ Wilmington, North Carolina 28403-3297, USA
}

\begin{abstract}
We conducted still-water time-course experiments on cultured larvae of the serpulid polychaete Hydroides dianthus (Verrill, 1873) to examine timing and patterns of gregarious and nongregarious settlement to better understand the conditions under which larvae of a gregarious species colonize new habitats. We first confirmed that these worms are aggregated in the field, and quantified patterns of association with a number of other common intertidal species. Patterns of negative association with spatial competitors is unlikely to have resulted from larval avoidance during settlement, because we found no difference in larval settlement in response to conspecifics with or without the solitary tunicate Ascidia interrupta present. We then examined the settlement of competent larvae in response to biofilm and conspecifics to determine the conditions under which the larvae of this gregarious species settle nongregariously. Larvae settled concurrently in response to both biofilm and conspecifics, starting approximately $4 \mathrm{~d}$ after fertilization, and response was of similar magnitude to both biofilm and to conspecifics for the first couple of days post-competency. While settlement in response to conspecifics continued in subsequent assays carried out over $70 \mathrm{~d}$ (at which time larvae began to die in culture), settlement in response to biofilm decreased abruptly after the peak, and ceased by Day 14. Settlement patterns were qualitatively similar regardless of previous exposure to substrata; similar results were obtained whether the whole population of larvae in culture was denied access to or daily provided access to 1 or both experimental substrata. Furthermore, these patterns of settlement did not change as larval planktonic period was prolonged. Of larvae settling during $24 \mathrm{~h}$ sample assays, the majority of larvae metamorphosed in response to biofilm during the first $6 \mathrm{~h}$, whereas metamorphosis in the final $6 \mathrm{~h}$ (between 18 and $24 \mathrm{~h}$ ) of the assays was primarily in response to conspecifics. These results are opposite to the pattern predicted by the desperate larva hypothesis, because some larvae settled in response to biofilm even after rejecting conspecifics the previous day. In fact, cultures of competent larvae appear to become more specific in terms of larval settlement in response to live adult conspecifics as the planktonic period is artificially prolonged.
\end{abstract}

KEY WORDS: Colonization · Gregarious settlement · Habitat choice ' Hydroides dianthus . Polychaete Resale or republication not permitted without written consent of the publisher

\section{INTRODUCTION}

Gregarious settlement is common among benthic marine invertebrates; at least 35 species representing 8 phyla produce larvae that settle preferentially on or near conspecific adults (reviewed in Burke 1986, Paw-

${ }^{*}$ Present address: Center for Population Biology, University of California, Davis, Davis, California 95616, USA

E-mail: rob@biogeek.ucdavis.edu lik 1992a). However, in order for larvae to respond gregariously, conspecifics must already be present. How, then, is the aggregation process initiated if larvae settle preferentially in response to conspecific adults? Aggregations of nonclonal species must initially develop through a 2-step process: solitary larvae first colonize a suitable but previously uninhabited substratum; gregarious settlement may then occur in response to these 'founders' (Toonen \& Pawlik 1994). Regarding the process of aggregation, several interre- 
lated questions arise: (1) Under what circumstances will larvae of gregarious species settle in the absence of conspecific cues? (2) Are these colonizers simply larvae that have searched unsuccessfully for adult conspecifics? (3) Does previous exposure influence the likelihood of gregarious larvae settling apart from conspecifics?

To date, studies of gregarious invertebrate larval settlement have focused mostly on the second step of aggregation, the selection of settlement sites on or near adult conspecifics on established substrata (reviews by Crisp 1974, 1984, Scheltema 1974, Chia \& Rice 1978, Burke 1986, Pawlik 1992a,b). These studies have repeatedly implicated chemical cues associated with adult conspecifics as being responsible for larval settlement responses, although the isolation and chemical characterization of specific cues have remained largely elusive (Pawlik 1992b). Gregarious settlement of Hydroides dianthus is no exception: larvae respond to an unidentified, water-soluble chemical cue associated specifically with the bodies of living conspecific worms (Toonen 1993, Toonen \& Pawlik 1996), although as with the congeneric worm $H$. elegans, a bacterial organic coating (biofilm) appears to be an important prerequisite for larval response to this inductive cue (Toonen \& Pawlik 1996, Walters et al. 1997, Bryan et al. 1998, Beckmann et al. 1999, Unabia \& Hadfield 1999). Also as with $H$. elegans, larvae of $H$. dianthus probably respond to a variety of cues when assessing substratum suitability, including a suite of chemical cues from bacteria and other common members of the fouling community, as well as hydrodynamic forces (e.g. Bryan et al. 1997, Lau \& Qian 1997, Walters et al. 1997, Bryan et al. 1998, Carpizo-Ituarte \& Hadfield 1998, Beckmann et al. 1999, Harder \& Qian 1999, Unabia \& Hadfield 1999). Although much attention has been focused on attempts to isolate specific chemical cues which induce gregarious larval settlement in a variety of invertebrate species, the initial colonization of new substrata is at least as important as gregarious settlement in understanding the development of nonclonal aggregations and in controlling biofouling by gregarious species. Yet the settlement patterns of larvae of gregarious marine invertebrates that colonize previously uninhabited substrata has been studied very little.

Larvae that colonize uninhabited substrata probably respond to physical, chemical or biological cues unrelated to the presence of conspecifics. One hypothesis for the initiation of aggregations is that larvae unable to locate a preferred substratum for settlement may become progressively less discriminatory in their substratum choice, and consequently more likely to colonize a new substrate (Knight-Jones 1951, 1953, Wilson 1953, Pechenik 1990 [review]). This theory, referred to as the 'desperate larva hypothesis' (Toonen \& Pawlik
1994), suggests that all larvae of a gregarious species should initially delay metamorphosis while searching for a suitable habitat, but could eventually colonize a new substratum if unsuccessful in locating conspecifics. Decreased substratum-specificity of larvae faced with a prolonged planktonic lifespan could be adaptive, because an aging larva should risk settlement in a poor site rather than die without settling. The ability for larvae to delay metamorphosis is widespread (reviews by Pechenik 1990, 1999) and is consistent with the intuitive predictions made by the desperate larva hypothesis. Alternatively, if larvae do not respond with desperation, individual larvae may differ genetically, physiologically or behaviorally and therefore have different likelihoods of accepting uninhabited biofilmed substrata for settlement.

Here we examine patterns of settlement among the larvae of the gregarious serpulid polychaete Hydroides dianthus and document differential settlement of competent larvae through time in response to experimental substrata. We address several questions in this manuscript. First, although $H$. dianthus has been shown to exhibit gregarious settlement in the laboratory (Scheltema et al. 1981, Toonen \& Pawlik 1996), is this species actually aggregated in the field? This is an important point to consider, because patterns of gregarious larval settlement in the laboratory are likely to have little biological relevance if conspecifics do not show an aggregated dispersion in the field. Second, could the settlement patterns of larvae in response to a spatial competitor account for aggregations of adults in habitats lacking those competitors? Third, do larvae of $H$. dianthus show any evidence of reduced substratumspecificity through a prolonged planktonic period, as predicted by the desperate larva hypothesis, and does previous experience of larvae affect that answer. Finally, we ask whether our laboratory assays indicate a difference in the timing of larval metamorphosis in response to biofilm and conspecifics.

\section{MATERIALS AND METHODS}

Study organism. Hydroides dianthus (Verrill, 1873) is a tube-dwelling serpulid polychaete that ranges from New England through the West Indies and is found commonly on the underside of rocks, on shell hash, and on other natural and anthropogenic hard substrata (Hartman 1969). Individuals are gonochoristic and reproduce sexually, with gametes broadcast every 2 to 4 wk at $23^{\circ} \mathrm{C}$ (Zuraw \& Leone 1968). Females release an average of 30000 ova, and males an average of $6 \times 10^{7}$ sperm per spawn (Zuraw \& Leone 1972). Trochophore larvae begin feeding 18 to $24 \mathrm{~h}$ after fertilization, and become competent to settle after about $5 \mathrm{~d}$ 
at $23^{\circ} \mathrm{C}$ (Scheltema et al. 1981). Settlement occurs only on biofilmed surfaces, but gregarious settlement additionally requires the presence of water-soluble chemical cues associated with bodies of live conspecifics (Toonen 1993, Toonen \& Pawlik 1996). Larvae are approximately $300 \mu \mathrm{m}$ long at competency, and undergo rapid and obvious morphological changes during metamorphosis that distinguish settled individuals from attached larvae (Scheltema et al. 1981, Carpizo-Ituarte \& Hadfield 1998).

Field associations of Hydroides dianthus. We collected 25 concrete cinder blocks from a pile of rubble at the base of the easternmost support for the drawbridge which provides access to Wrightsville Beach, North Carolina, USA. These blocks were apparently scrap that had been dumped into the intertidal sometime in the recent past, and had since been colonized by a variety of fouling invertebrates. The position of the blocks was such that they would be exposed for only a short period of time during very low $(-20 \mathrm{~cm}$ or lower) tides. We brought these blocks into the laboratory and determined nearest-neighbor and quadrat contents in order to assay associations between Hydroides dianthus and other common fouling invertebrates. Focal animals for nearest-neighbor analyses were chosen by blindly selecting a spot on the block with a probe until a live worm was contacted. We also blindly placed a $5 \times 5 \mathrm{~cm}$ wire frame on each block and identified and counted the contents of each quadrat. We chose this quadrat size with the intention of comparing natural (primarily Mercenaria sp. shell hash) and anthropogenic substrata, but found no qualitative differences in faunal associations between the two (Toonen unpubl. data). Although these quadrats were relatively small, as many as 6 species (and up to 25 individuals) were included in them, and interactions among sessile fouling species are likely to occur over such relatively small distances. In addition to $H$. dianthus, other common fouling invertebrates found in these quadrats included: Botryllus planus (colonial tunicate), Chthamalus fragilis (barnacle), Schizoporella unicornis (encrusting bryozoan), Spirorbis sp. (tubiculous polychaete), Aplysilla longispina (sponge), Ascidia interrupta (solitary tunicate), Ecteinascidia turbinata (solitary tunicate), Microciona prolifera (sponge), and Tubularia crocea (stalked hydroid). We excluded rare animals ( $<2 \%$ of total abundance) from these analyses for statistical reasons.

Nearest neighbors were recorded and index of association $(v)$ tests were calculated for species identified in our quadrats following Rejmanek \& Leps (1996). We determined the significance of association for each species with Hydroides dianthus using a $2 \times 2$ goodness-of-fit test (Sokal \& Rohlf 1981). For those species that were sufficiently abundant to allow homogeneity of variance to be confirmed using a log-ANOVA test (Sokal \& Rohlf 1981), we also used a Spearman's rank correlation coefficient to test statistical associations among species abundances in the quadrats (again following Rejmanek \& Leps 1996).

General spawning and fertilization techniques. During the summers of 1992 and 1993, adult Hydroides dianthus were collected from large (125000 l) seawater settling tanks at the former Wrightsville Beach desalination plant, or from the field at Banks Channel, under the drawbridge access to Wrightsville Beach, North Carolina. Aggregations of $H$. dianthus were kept in running, unfiltered seawater until spawned.

Spawning was induced by breaking individual worms from their calcareous tubes (Strathmann 1987). Each female was placed into a $10 \mathrm{~cm}$ dish containing $50 \mathrm{ml}$ of $1 \mu \mathrm{m}$ filtered seawater, and each male was placed on a watch glass without seawater. Eggs from 15 to 25 females were combined prior to fertilization by sperm from a single male that produced the highest density of motile sperm. Eggs were fertilized by placing dishes containing the spawn of a group of females on a shaker table rotating at $50 \mathrm{rpm}$ and initially adding 5 drops of sperm suspension ( $1 \mathrm{ml}$ 'dry' sperm diluted in $20 \mathrm{ml}$ of $1 \mu \mathrm{m}$ filtered seawater). Additional sperm suspension was added twice thereafter at 10 min intervals, the volume being doubled with each addition (i.e. 10 drops, then 20 drops). Each experiment was run with a different culture of mixed-parentage larvae produced from the spawning by a different adult male and group of female worms.

General larval culture techniques. Trochophore larvae of Hydroides dianthus were cultured at 10000 larvae $\mathrm{l}^{-1}$ using techniques adapted from Pawlik (1986). Each experiment was performed on a different population of 90000 larvae, pooled from the spawns of about 25 females. For most experiments, larvae were kept in three $4 \mathrm{l}$ wide-mouth glass jars each containing $3 \mathrm{l}$ of $1 \mu \mathrm{m}$ filtered seawater. Culture jars were maintained in $21 \pm 2{ }^{\circ} \mathrm{C}$ constant-temperature water baths beneath two $40 \mathrm{~W}$ fluorescent lamps set to a 15:9 h light:dark photoperiod (also adapted from Pawlik 1986). The contents of each jar were gently agitated with filtered air bubbling at approximately 2 bubbles $\mathrm{s}^{-1}$ from the tip of a $23 \mathrm{~cm}$ Pasteur pipette resting on the bottom of the jar.

Larval cultures were cleaned every second day, and larvae were resuspended in a clean jar filled with 31 of $1 \mu \mathrm{m}$ filtered seawater; used jars were scrubbed in hot freshwater and allowed to air-dry prior to reuse. Cultures were cleaned daily after $6 \mathrm{~d}$ to keep cultures as clean as possible and minimize development of a biofilm and subsequent settlement in culture jars. Based on the work of Zuraw \& Leone (1968) and Scheltema et al. (1981), larvae were fed monospecific cultures of the diatom Phaeodactylum tricornutum (Boh- 
lin) at $10^{5}$ cells $\mathrm{ml}^{-1}$ each time the larval cultures were cleaned. The algal culture methods were adapted from Guillard (1975).

Larval settlement assays and experimental substrata. Each larval assay was performed by removing 25 larvae from a well-mixed culture and placing them in a covered $10 \mathrm{~cm}$ plastic petri dish containing $25 \mathrm{ml}$ of $1 \mu \mathrm{m}$ filtered seawater and a single biofilmed or adult slide; dishes were then placed into a constantly illuminated $20^{\circ} \mathrm{C}$ incubator for $24 \mathrm{~h}$. For each experiment, unless otherwise specified, there were 12 replicate sample assays (run simultaneously) for each substratum (described in the following paragraphs). Slides were examined through a dissecting microscope, after being rinsed gently with $1 \mu \mathrm{m}$ filtered seawater to remove larvae, and settled juveniles (identified by rudimentary crown and tube formation) were counted as they were individually removed (Scheltema et al. 1981, Toonen \& Pawlik 1996).

We used etched-glass cytology slides (Fisher $75 \times$ $25 \mathrm{~mm}$ etched slides) for all experimental substrata because we found that settlement on these slides was much higher than on unfrosted microscope slides (Toonen unpubl. data). In each experiment, larvae were presented with a single experimental substratum in a no-choice experiment. Experimental substrata consisted of either a single biofilmed or adult conspecific slide, unless otherwise specified.

Biofilmed slides were made by placing slides in running, unfiltered seawater for at least $5 \mathrm{~d}$, so that they became coated with an organic/microbial film. We did not measure the organic content or determine the community composition of the biofilm on the slides, but we assume that variation in the microbial community and organic content did not affect larval settlement significantly; there was no significant difference in the response of larvae to slides that had been biofilmed for $5 \mathrm{~d}, 2 \mathrm{wk}$ and 2 mo (R.J.T. unpubl. data). Furthermore, although $1 \mu \mathrm{m}$ filtered seawater is not axenic and after $24 \mathrm{~h}$ an organic film is likely to form on the interior surfaces of the culture dishes, we did not ever find a single larva metamorphosed on any surface other than the glass slides in any of our culture assays.

Conspecific slides were similarly treated, but after $5 \mathrm{~d}, 5$ small (3 to $5 \mathrm{~cm}$ long) conspecific worms were attached using Thick-gel Superglue (cyanoacrylate adhesive). There were no obvious signs of toxicity of the glue to adult worms, and cyanoacrylate had no measurable effect on larval settlement (Toonen unpubl. data). The slides were then returned to running seawater for at least $1 \mathrm{~h}$ before use in an assay. Adult and biofilmed slides used concurrently were submerged for the same period of time, and kept together in running, unfiltered seawater for subsequent assays. Before adding slides to assay dishes, each slide was scraped with a straight-edge razor to remove any macroscopic organisms (such as filamentous algae or protozoans). Adult slides were similarly scraped, but a toothbrush was also used to remove any organisms from the tubes of adults. We could not use unfilmed 'clean' slides for settlement substrata in these experiments because competent larvae of Hydroides dianthus refuse to settle on unfilmed surfaces, even in the presence of inductive cues (Toonen \& Pawlik 1996).

For simplicity, hereafter we refer to these experimental substrata as 'biofilm' and 'conspecifics'.

Larval predator/competitor effects on settlement choice. To examine whether avoidance at the time of larval settlement could account for the negative associations found between Hydroides dianthus and other fouling species (see 'Field associations' section), we conducted a series of sample assays with the common spatial competitor and potential larval predator, Ascidia interrupta. We attached a single small tunicate to some substrata previously used as biofilm and conspecifics to compare larval response to biofilm and conspecifics with or without the tunicate present. In preparing the +tunicate slides, we selected individuals that were too small to currently act as larval predators so that they would not consume larvae and alter our assay sample sizes. Using small tunicates for this purpose also simplifies handling and did not require any modification of assay vessels (large tunicates would not fit in the $10 \mathrm{~cm}$ plastic petri dishes).

We cultured larvae as above, and after $7 \mathrm{~d}$ exposed samples of larvae to each of the following experimental substrata: (1) conspecific adults, (2) Ascidia interrupta attached to a biofilmed slide, (3) biofilm, or (4) A. interrupta attached to a conspecific adult slide.

The significance of differences in the settlement of larvae in response to the 4 experimental substrata present in the larval predator experiment were assessed with a parametric 1-way ANOVA after -log $[1 /(x+1)]$ transformation to fit assumptions of parametric statistics. Homogeneity of variance was confirmed using a log-ANOVA test for homogeneity of variances (Sokal \& Rohlf 1981), and post hoc comparisons were done with a Bonferroni correction for unplanned contrasts among means.

Settlement on biofilm or conspecifics during a prolonged planktonic period. We assayed larval response to experimental substrata repeatedly throughout a prolonged planktonic period to determine whether larvae show decreased substratum-specificity when forced to delay metamorphosis. Larvae were sampled for response to biofilm or conspecifics daily for the first week, and then weekly thereafter until the experiment was ended due to larval depletion after $70 \mathrm{~d}$. Early in 
the experiment, assays were run daily to examine larval settlement shortly after reaching competency, because this is the period most likely to show shortterm variation in larval settlement rates (Toonen 1993, Toonen \& Pawlik 1994).

Percentage settlement data were transformed by arcsine square-root or $-\log [1 /(x+1)]$ to meet assumptions of normality and homogeneity of variance. Heteroscedastic data (determined using a log-ANOVA test for homogeneity of variances) were first transformed using $-\log [1 /(x+1)]$, and then analyzed with a Student's $t$-test corrected for unequal variances $\left(t^{\prime}\right)$, with the critical value and degrees of freedom being derived from a weighted average of the 2 samples being tested (Sokal \& Rohlf 1981). Post hoc comparisons among means were performed using Scheffé comparisons at $\alpha=0.05$.

We also compared the results of our experiment here to that of previous work in which the entire culture of larvae was either: (1) exposed previously to biofilm daily prior to no-choice sample assays being conducted, or (2) exposed previously to both biofilm and conspecifics daily prior to running no-choice sample assays (see Toonen \& Pawlik 1994 for methods and data). Data are compared as both the total mean proportion of larvae settling in response to biofilm and conspecifics per assay throughout the planktonic period and as the actual time course over which these assays were conducted. We analyzed statistical differences between these experiments using a 3-way ANOVA on arcsine square-root transformed percentage settlement data (after Sokal \& Rohlf 1981). Although parametric statistics are robust to some deviation from normality and homogeneity of variance assumptions (Sokal \& Rohlf 1981), after best-fit transformation to parametric assumptions, our data still fail both the Shapiro-Wilks test for normality and Bartlett's test for homogeneity of variance (see 'Results'). Because we have no quantitative manner in which to assess whether the violation of parametric assumptions here is within that robust range, we also conducted a nonparametric 2-way Friedman's test on ranked data for each biofim and conspecifics separately.

Timing of larval metamorphosis on experimental substrata. To investigate the more immediate responses of competent larvae to experimental substrata, we conducted sample assays with cultures of $7 \mathrm{~d}$ old larvae to compare when larvae settled in response to biofilm as compared to conspecifics. Because scoring these assays is labor-intensive and relatively slow, it was impossible to remove settled larvae from substrata individually during the experiment as for previous assays. Therefore, we present the proportion of metamorphosed larvae that had completed primary tube formation in each replicate assay rather than some measure of individual settlement per unit time. Slides were examined hourly for the first $6 \mathrm{~h}$, then every $3 \mathrm{~h}$ until $18 \mathrm{~h}$, and finally again at $24 \mathrm{~h}$.

Differences in the timing of settlement between larvae on biofilmed and adult slides in sample assays were tested with a 1-way ANOVA after again testing for conformity of $-\log [1 /(x+1)]$-transformed data to assumptions of parametric statistics.

\section{RESULTS}

\section{Field associations of Hydroides dianthus}

Of the 25 focal individuals of Hydroides dianthus selected, 16 nearest neighbors were conspecifics, confirming that $H$. dianthus is highly aggregated in the field $(\mathrm{R}=0.45, \mathrm{z}=15.57, \mathrm{p}<0.05)$. Analysis of quadrat data suggests that $H$. dianthus is positively associated with conspecifics $(v=0.94, \mathrm{df}=1, \mathrm{p}<0.05)$, and negatively associated with several other common fouling invertebrates: Botryllus planus, Chthamalus fragilis, Ascidia interrupta, Ecteinascidia turbinata and Tubularia crocea $(v=-0.47$ to $-0.94, \mathrm{df}=1, \mathrm{p}<0.05)$. Indices of association calculated for each of the other common species identified in the quadrat sampling (Schizoporella unicornis, Spirorbis sp., Aplysilla longispina, and Microciona prolifera) did not differ significantly from zero $(v=-0.05$ to $-0.37, \mathrm{df}=1, \mathrm{p}>0.05)$.

Only 4 species could be transformed to meet homogeneity of variance assumptions required to compute Spearman's rank correlations with Hydroides dianthus: Botryllus planus, Spirorbis sp., Aplysilla longispina, and Microciana prolifera (Cochran's $Q<0.75$, Bartlett's test $\mathrm{p}>0.05$ ). Of these species, individual abundance of $H$. dianthus was significantly negatively correlated with only B. planus $\left(\mathrm{r}_{\mathrm{s}}=-0.49, \mathrm{df}=1, \mathrm{p}<0.05\right)$.

\section{Larval competitor/predator effects on settlement choice}

We did not see any obvious effects of the inclusion of a potential larval competitor/predator on experimental substrata. Significantly more larvae settled in response to substrata with conspecifics (conspecifics \& conspecifics + Ascidia interrupta) than to those lacking conspecifics (biofilm \& biofilm $+A$. interrupta) (ANOVA, $F=13.93$, df $=3, p<0.05$ ). There were no significant differences in the response of larvae to either: (1) conspecifics with or without $A$. interrupta $(t=0.36, \mathrm{df}=10, \mathrm{p}>0.05)$ or (2) biofilm with or without $A$. interrupta present $(t=0.62$, df $=10, \mathrm{p}>0.05$ ). Larval response to substrata with $A$. interrupta present was equivalent to that of the same substratum without the tunicate attached (Fig. 1). 


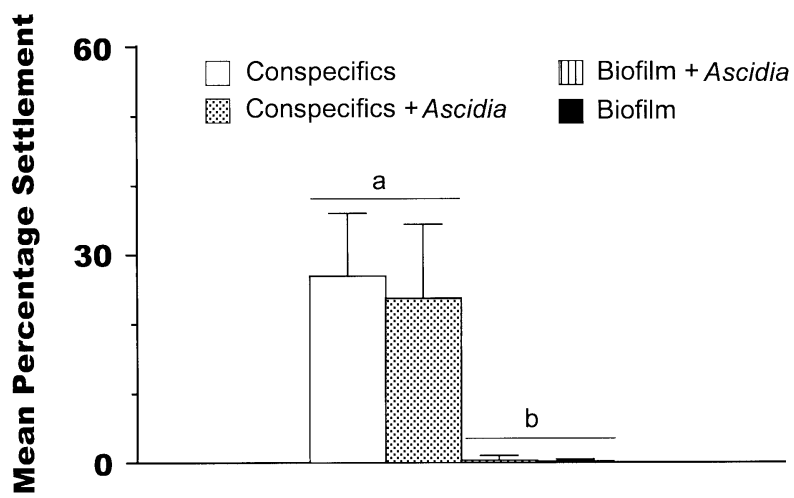

Fig. 1. Hydroides dianthus. Mean (+1 $\mathrm{SE}, \mathrm{n}=12)$ percentage settlement of samples of 25 larvae exposed to biofilm and conspecifics with and without a potential competitor and larval predator, (Ascidia interrupta) present. Experimental substrata (conspecifics, conspecifics $+A$. interrupta, $A$. interrupta alone on a biofilmed slide, and biofilm alone) were presented to larvae after $7 \mathrm{~d}$ culture in sample assays (see 'Materials and methods'). Lines above bars indicate groups $(\mathrm{a}, \mathrm{b})$ among which the means did not differ significantly (Scheffé, $\alpha=0.05$ )

\section{Settlement on biofilm or conspecifics during a prolonged planktonic period}

Specificity of settlement did not decrease over a planktonic lifespan extended for 10 wk (Fig. 2). Settlement in response to biofilm occurred primarily within the first week, and did not increase throughout a planktonic larval lifespan prolonged artificially in excess of 10 times the precompetent period (Fig. 2). Gregarious settlement in response to conspecifics, however, did not decrease throughout the entire experiment (Fig. 2). The bars representing settlement on biofilmed slides at Weeks 3, 5, 6, 7, and 9 each represent a single juvenile ( 1 of 300 larvae in each case) that settled in response to biofilm. There was no significant difference between the settlement of larvae in response to biofilmed and adult slides at Days $4(t=1.33$, $\mathrm{df}=22, \mathrm{p}>0.2)$ or $5(t=2.08, \mathrm{df}=22, \mathrm{p}>0.05)$. From Days 6 through 70, however, significantly more larvae settled in response to adult slides than to biofilmed slides $\left(t^{\prime}=3.99\right.$ to $\left.9.74, \mathrm{df}=11, \mathrm{p}<0.01\right)$. Statistical significance is similar whether comparing the percentage of assayed larvae settling in response to each substrate or the ratio of settled larvae responding to biofilmed (Bio) compared to adult (Ad) slides (i.e. Ad/Ad + Bio).

By comparing these data to those of Toonen \& Pawlik (1994), in which larvae were either presented with only biofilm or both biofilm and conspecifics daily prior to assaying larval settlement response, we can examine the effect of previous exposure to experimental substrata on the pattern of larval settlement in these assays. We found no evidence to suggest that previous larval exposure to experimental substrata altered the proportion of larvae settling in response to either biofilm or conspecifics (Fig. 3), and this result did not change with the 'age' of the larvae (Fig. 4). Results were qualitatively similar whether analyzed using parametric (Table 1A) or nonparametric (Table 1B) statistics. Regardless of experimental treatment, we could find no case in which specificity of larval settlement decreased over a prolonged planktonic period. In fact, if anything, larval substratum-specificity actually increased throughout the planktonic period as larvae ceased to settle in response to biofilm (Fig. 4).

\section{Timing of larval settlement on experimental substrata}

Among $7 \mathrm{~d}$ old larvae, metamorphosis within the first $6 \mathrm{~h}$ of sample assays occurred predominantly in

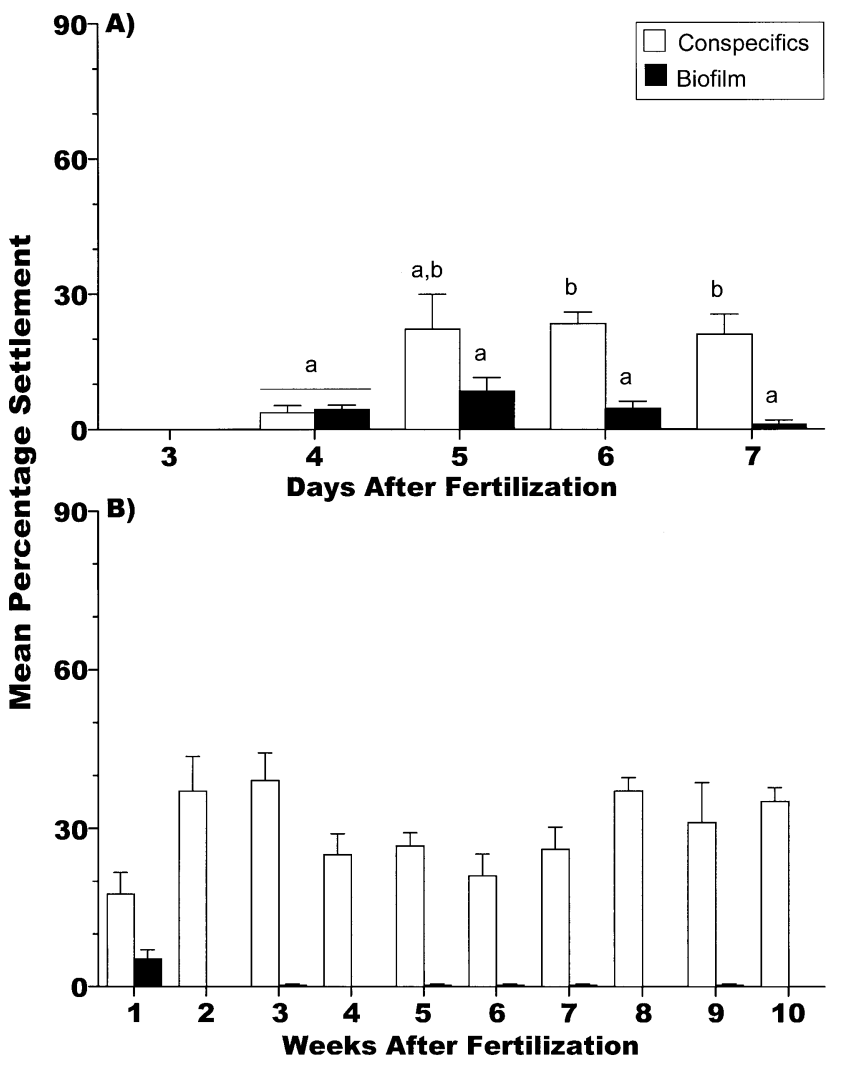

Fig. 2. Hydroides dianthus. Mean $(+1 \mathrm{SE}, \mathrm{n}=12)$ percentage settlement of samples of 25 larvae from cultures kept in clean jars for $10 \mathrm{wk}$. Larvae were assayed for response to conspecifics and biofilm in sample assays (see 'Materials and Methods'). Assays were run daily during the first $7 \mathrm{~d}$, and weekly thereafter. (A) Daily sample assays of larvae from clean culture jars to assess larval response to substrata shortly after reaching competency. (B) Weekly sample assays of larvae from clean culture jars to assess larval substratumspecificity over the planktonic lifespan when denied access to substrata; data for Week 1 are mean of results in (A) 


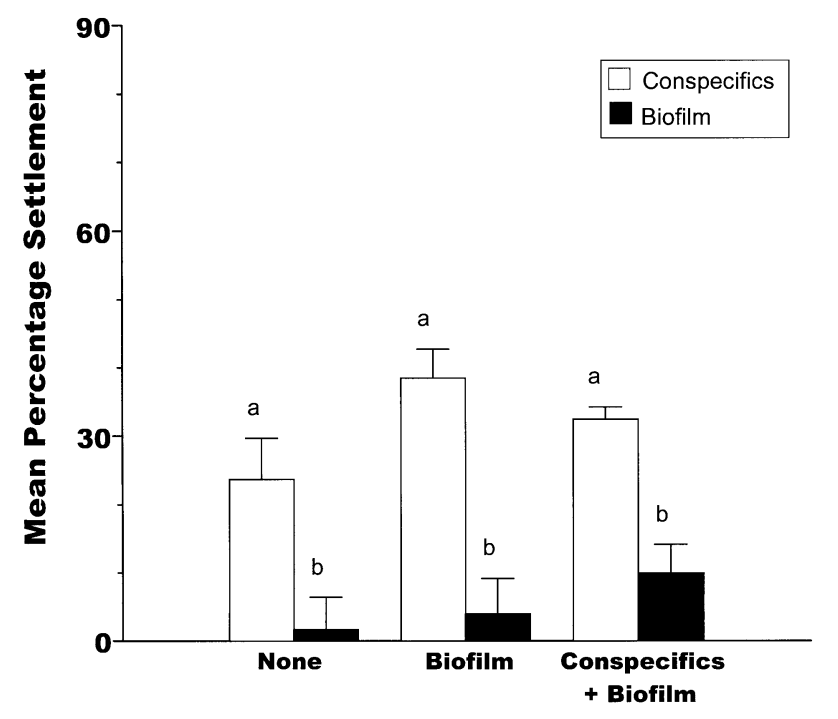

Previous Exposure to Experimental Substrata

Fig. 3. Hydroides dianthus. Comparison of total mean percentage settlement of larvae per assay throughout the planktonic period with different previous exposure to experimental substrata. Sample size varied between experimental groups ( $\mathrm{n}=72$ to 156 replicate samples of 25 larvae each), and bars indicate overall means of all sample assays conducted in each experiment +1 SE. Larvae were cultured and assayed as described in 'Materials and methods', with samples of larvae exposed to substrata in no-choice experiments using biofilm or conspecifics daily during the first week, and then weekly thereafter. Letters above bars indicate groups among which the means did not differ significantly (Scheffé, $\alpha=0.05$ )

response to biofilm, whereas metamorphosis in the final $6 \mathrm{~h}$ (18 to $24 \mathrm{~h}$ ) was in response to primarily conspecifics (Fig. 5). The majority of larvae that settled in these assays attached within the first hour, and it is important to note that these results are differences in the timing of metamorphosis, not larval attachment. Because we did not remove any larva that attached in these assays, and simply scored the time at which the morphology of an attached larva switched to that of an attached juvenile, the numbers of settlers in Fig. 5 are the cumulative percentages of larvae that completed metamorphosis on each experimental substrata in our sample assays. Of those larvae that completed metamorphosis during the first $12 \mathrm{~h}$, significantly more responded to biofilm than to conspecifics (ANOVA, $F=16.3606$, df $=1, \mathrm{p}<0.05$ ), but few juveniles recruited to biofilmed slides throughout the remaining $12 \mathrm{~h}$ of the $24 \mathrm{~h}$ assay period (Fig. 5). Few of the larvae that metamorphosed in response to conspecifics completed the process within the first $12 \mathrm{~h}$ (Fig. 5). However, there was a sudden increase between 18 and $24 \mathrm{~h}$, such that the cumulative percentage of metamorphosed larvae scored at the end of the $24 \mathrm{~h}$ assay period was significantly higher in response to conspecific adults than in responseto biofilm $(t=22.48, \mathrm{df}=1$, $\mathrm{p}<0.05)$.

\section{DISCUSSION}

Gregarious settlement of Hydroides dianthus has been studied previously by a number of researchers (e.g. Leone 1970, Scheltema et al. 1981, Mullineaux \& Garland 1993, Toonen \& Pawlik 1994, 1996), but to the best of our knowledge no study has yet demonstrated the spatial pattern of aggregation among these worms in the field. Here we show that $H$. dianthus is highly aggregated (positively associated) with conspecifics and negatively associated with several other common

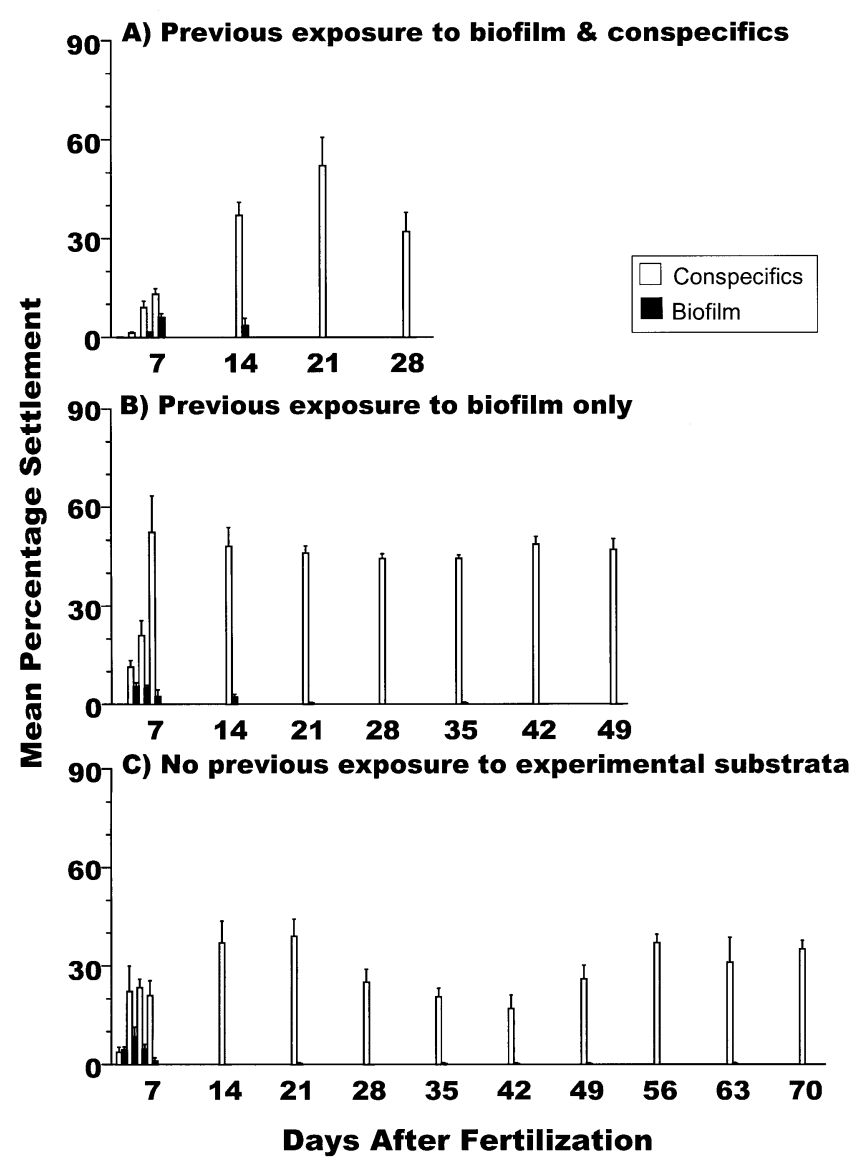

Fig. 4. Hydroides dianthus. Mean (+1 $\mathrm{SE}, \mathrm{n}=12)$ percentage settlement of samples of 25 larvae throughout the planktonic period with different previous exposure to experimental substrata. Cultures were maintained until depleted by larval settlement, but only the mean percentage of samples of larvae assayed in no-choice experiments are reported here (see Toonen \& Pawlik 1994 for additional data). Larvae were cultured and exposed previously to substrata as described in Fig. 3 legend (see 'Materials and methods'). Statistical comparisons in Table 1 
Table 1. Comparison of arcsine-transformed mean percentage settlement among larvae within the 3 previous exposure regimes listed in Fig. 4. Day: days after fertilization, Expt: previous exposure regime (none, biofilm only, both biofilm and conspecifics); Substrate: substrate type was either biofilm or conspecifics. (A) Summary of results from a 3-way parametric ANOVA with a best-fit transformation to assumptions of parametric statistics; although data fail statistical tests for conformity to parametric statistics, the complete analysis of these data including the interaction terms requires this statistical method; these data are compared to the nonparametric analyses in (B). (B) Nonparametric 2-way Friedman's tests on ranked data for each substrate separately

\begin{tabular}{|lrrrr|}
\hline (A) & & & & \\
Source & DF & SS & \multicolumn{1}{c|}{$F$} & \multicolumn{1}{c|}{$\mathrm{p}$} \\
\hline Day & 1 & 0.14 & 11.04 & 0.002 \\
Expt & 2 & 0.16 & 3.13 & 0.053 \\
Substrate & 1 & 0.13 & 4.92 & 0.031 \\
Day $\times$ Expt & 2 & 0.13 & 3.22 & 0.049 \\
Day $\times$ Substrate & 1 & 0.44 & 15.53 & $<0.001$ \\
Expt $\times$ Substrate & 2 & 0.09 & 2.65 & 0.081 \\
Day $\times$ Expt $\times$ Substrate & 2 & 0.17 & 3.21 & 0.050 \\
& & & & \\
(B) & & & & \\
Factor & DF & $F_{\mathrm{r}}$ & $\mathrm{p}$ & \\
\hline Conspecifics & & & & \\
Day & & & & \\
Expt & 9 & 15.99 & 0.067 & \\
Biofilm & 2 & 3.80 & $>0.1$ & \\
Day & & & & \\
Experiment & 9 & 18.80 & 0.027 & \\
& 2 & 1.65 & $>0.1$ & \\
\hline
\end{tabular}

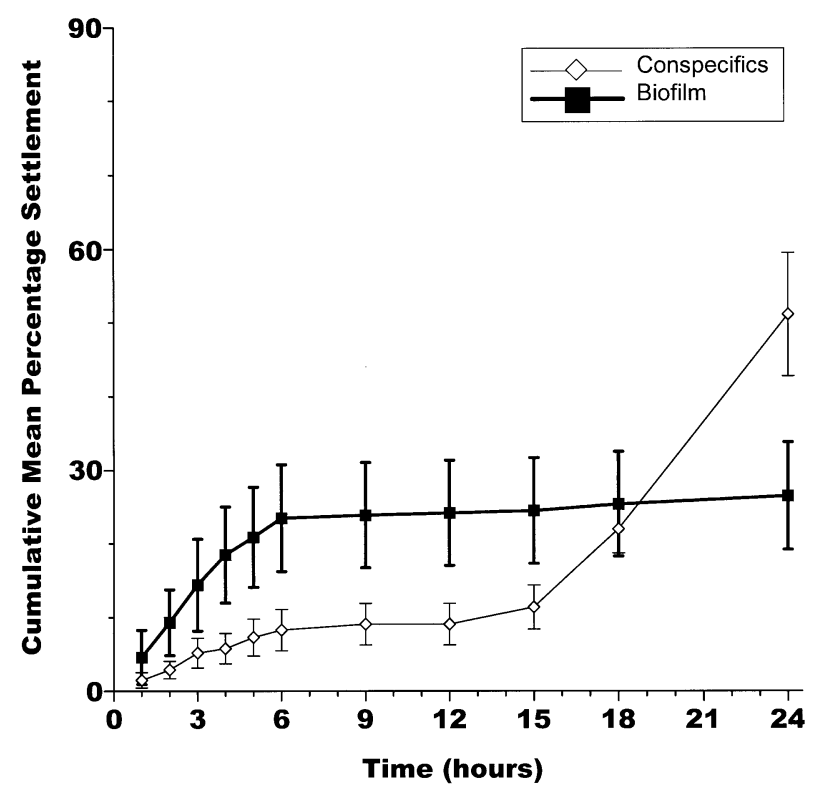

Fig. 5. Hydroides dianthus. Cumulative mean proportion of settling of $7 \mathrm{~d}$ old larvae $(\mathrm{n}=10$ replicate samples of 25 larvae each) that metamorphosed in response to conspecifics or to biofilm throughout $24 \mathrm{~h}$ sample assays (see 'Materials and methods') fouling invertebrates including the colonial tunicate Botryllus planus, the spirorbid polychaete Spirorbis sp., the solitary tunicates Ascidia interrupta and Ecteinascidia turbinata, and the encrusting sponge Microciona prolifera. These other fouling invertebrates are probably competitors for space, and some (the solitary tunicates in particular) are likely to act as larval predators as well.

The strong negative association between the solitary tunicate Ascidia interrupta and Hydroides dianthus documented in the field did not translate into a decrease in larval settlement in response to conspecifics in laboratory assays (Fig. 1). In our assays, we used a single small tunicate to prevent tunicates from consuming larvae and affecting sample sizes, and although we tried to include the largest individual possible given our experimental design, we may have not provided a sufficient individual density of competitors to affect larval settlement choice. We wanted to avoid larval predation by the tunicates, because although these are perfectly capable of ingesting polychaete larvae, high rates of larval predation by tunicates in the laboratory does not seem to translate to significant differences among settlement plates in the field (Young 1989). Therefore, both larval predation and direct larval avoidance seem unlikely explanations for the negative association between these 2 species observed in the field. However, Grosberg (1981) found that recruitment of Hydroides sp. to settlement plates in Eel Pond at Woods Hole, Massachusetts, was significantly reduced in the presence of high densities of botryllid tunicates (15 individuals on a $5 \times 5 \mathrm{~cm}$ plate), but not in the presence of low tunicate densities (5 individuals/ plate). Grosberg concluded that larvae of species showing such density-dependent recruitment patterns are most probably capable of recognizing the density of dominant spatial competitors and rejecting substrata when that density exceeds a certain threshold (Grosberg 1981). The tunicate used by Grosberg (Botryllus schlosseri) is colonial, and 15 zooids of this tunicate actually form a smaller mass than 1 of the solitary $A$. interrupta used in our assays; however, because we did not address density of competitors directly in these assays, we cannot rule out the possibility that a higher density of tunicates might have resulted in larval avoidance. Alternatively, the negative association could also be the result of post-settlement mortality due to overgrowth by the tunicate itself, or differential effects of overgrowth on these species by other cooccuring fouling species (e.g. Stachowicz et al. 1999).

Hydroides dianthus is significantly aggregated in the field $(\mathrm{R}=0.45, \mathrm{z}=15.57, \mathrm{p}<0.05)$, with 16 of 25 individuals having a conspecific as their nearest neighbor. Gregarious settlement of larvae in response to chemical cues associated specifically with conspecific 
adults is the most likely explanation for this pattern of dispersion, given substantial preferential settlement in response to live adult conspecifics in laboratory experiments (e.g. Scheltema et al. 1981, Toonen 1993, Toonen \& Pawlik 1994, 1996). Gregarious settlement of marine invertebrates has been extensively studied (e.g. Burke 1986, Pawlik 1992a), but the mechanisms by which aggregations are initiated on previously uninhabited substrata have received much less attention. We are interested in the infrequently addressed question of how monospecific aggregations of species with gregarious larvae first form. Decreased substratum-specificity over the planktonic lifespan was first proposed by Knight-Jones $(1951,1953)$ and Wilson (1953) to account for those larvae that initiate aggregations. Our results provide no support for this hypothesis. If gregarious larvae that colonize uninhabited substrata are the result of decreased substratum-specificity, settlement on biofilmed slides should occur only with larvae that have had their planktonic lifespan prolonged, and that have never previously encountered conspecific adults. The present study provides evidence that, for $H$. dianthus at least, settlement in response to biofilm and conspecifics begins concurrently, and does not differ in magnitude for the first couple of days post-competency (see Days 4 and 5, Fig. 2). Furthermore, the proportion of larvae settling in response to biofilm throughout the planktonic period did not differ regardless of previous exposure of larvae to any combination of these experimental substrata (Fig. 3). In direct opposition to the predictions of the desperate larva hypothesis, settlement of larvae in response to biofilm and conspecifics occured similarly among cultures with no previous exposure to experimental substrata (Fig. 4C), previous exposure to biofilm only (Fig. 4B), and even in cultures in which the entire population of larvae had previously been exposed to both conspecifics and biofilm daily (Fig. 4A). These results indicate that, if anything, larvae of $H$. dianthus become more substrate-specific throughout a prolonged planktonic period as larvae cease to settle in response to biofilm, but continue to settle in response to live adult conspecifics (Figs $3 \& 4$ ). This result is most likely explained by the culling of those larvae willing to accept biofilm as a suitable cue for settlement. Metamorphosis of larvae in response to biofilm occurred primarily within the first $6 \mathrm{~h}$ of the $24 \mathrm{~h}$ assay period (Fig. 5), whereas metamorphosis in response to conspecifics peaked during the final $6 \mathrm{~h}$ (i.e. 18 to $24 \mathrm{~h}$ ). One potential explanation for the observed difference in settlement is that there may be a relationship between the time required to complete settlement and metamorphosis and the number of cues which larvae assess in making the decision to accept or reject that substratum. Alternatively, larvae may take longer to encounter the source of cue production associated with adult conspecifics, whereas larvae responding to a bacterial cue are more likely to encounter the source with greater frequency. To the best of our knowledge, there is currently no data to support or deny the existence of such a relationship, although other authors have shown similar differences in response time among groups of larvae, and invoked a similar relationship to account for more rapid settlement in response to certain substrata than others (e.g. Mackay \& Doyle 1978). This remains a subject worthy of further attention, and as studies on the physiological basis of larval response to metamorphic cues become more sophisticated and approach the functional mechanisms by which settlement of larvae is stimulated, our understanding of data such as these will be greatly advanced (e.g. Holm 1990, Pawlik 1990, Fenteany \& Morse 1993, Carpizo-Ituarte \& Hadfield 1998, Pechenik \& Qian 1998, Beckmann et al. 1999, Unabia \& Hadfield 1999).

Research on the congeneric worm Hydroides elegans has found that larvae of this species settle in response to a cue derived from a number of common marine bacteria (Bryan et al. 1998, Beckmann et al. 1999, Harder \& Qian 1999, Unabia \& Hadfield 1999). Harder \& Qian found that both bio-organic films and extracts from conspecific $H$. elegans and from the arborescent bryozoan Bugula neritina all induced rapid settlement, and traced activity to a series of dissolved free amino acids (DFAA). Beckmann et al. found a significant correlation between rate of DFAA reduction, bacterial film development and larval metamorphosis in $24 \mathrm{~h}$ larval settlement assays with larvae of $H$. elegans, but concluded that induction by the bacterial film rather than perception of DFAA directly triggers larval settlement. The authors went on to argue that if putative signaling compounds, such as DFAA or the exudates from live conspecific worms, serve as a source of nutrition for inductive bacterial strains, then there is a systematic error introduced into any explicit investigation of the efficacy of metamorphic inducers (Beckmann et al. 1999). Fortunately, we see no evidence for such an effect here; switching the glass slides used as the substrate for these assays and repeating assays did not significantly alter the proportion of larvae settling in response to biofilm and conspecifics, and an examination of the bacterial communities on a number of slides previously assigned to biofilm and conspecific treatments did not reveal any consistent differences in the microbial community present (Esham \& Toonen unpubl. data). We did encounter a couple of biofilmed slides in the course of our experiments which elicited settlement nearly equivalent to that observed in response to conspecific slides, but were unable to isolate the cause of the high settlement; although we did discover that an unidentified 
rod-shaped bacterium was consistently present, we were unsuccessful at culturing and repeating the high proportion of settlement in response to either pure cultures of these rod-shaped bacteria or nonspecific cultures of bacterial films isolated from these slides (Esham \& Toonen unpubl. data). Unlike response to the unidentified bacteria, response to conspecificinhabited-substrata was consistently repeatable, and the cue could be both extracted and consistently shown to induce settlement (Toonen \& Pawlik 1996). A similar result was obtained with the congeneric worm $H$. ezoensis, in which extractions of aggregations of conspecifics were found to contain a novel monoacyl glycerol that induces larval settlement (Okamoto et al. 1998, Watanabe et al. 1998). However, unlike $H$. dianthus and $H$. ezoensis, aggregations of $H$. elegans may not result from gregarious settlement of larvae, and the specific chemical and hydrodynamical cues leading to aggregation in this congener remain a subject of controversy (e.g. Bryan et al. 1997, 1998, Lau \& Qian 1997, Walters et al. 1997, Carpizo-Ituarte \& Hadfield 1998, Beckmann et al. 1999, Harder \& Qian 1999, Unabia \& Hadfield 1999).

Our experiments provide the data to reject the desperate larva hypothesis for the initial colonization of substrata by larvae of the gregarious tubeworm Hydroides dianthus. However, our data do not provide us with an unambiguous explanation for nongregarious settlement by larvae of this species. There remain a number of other hypotheses which could account for the initial colonization of previously uninhabited substrata by larvae of a gregarious species. First, larvae may simply have an imperfect ability to assess the suitability of substrata and some individuals essentially make a mistake in their choice of substrate as a result. Under this error variance hypothesis, all larvae are searching for the same specific habitat-suitability cues, but each individual has some probability of incorrectly assessing the cues present. Given that the number of errors made by individuals should be independent of time (unless larvae are capable of learning: see following sentence), there should be no fixed relationship between settlement of larvae on substrata of each type and time in the plankton. A second possibility is that larvae are initially incapable of assessing habitat suitability without error, but are capable of remembering previous encounters with substrata, and that this learning allows larvae to become better at selecting conspecific-inhabited substrata with time. A third possibility is that larvae are again all searching for the same habitat cues, but require some minimal developmental time in which to develop the necessary physiological or sensory machinery to properly assess habitat suitability. Under the developmental constraint hypothesis, larvae are constrained to making their choice based on incomplete or inaccurate sensory input early in the competent period, but become more proficient at habitat assessment as they continue to develop. A final possible explanation is that larvae have an innate preference for different substrata and that settlement in response to biofilm should not be viewed as a mistake by the larvae of a gregarious species, but rather a polymorphism in individual larval settlement preference. Individual larval settlement preference may be the result of differences in larval energetic condition, maternal provisioning, or the result of some heritable genetic effect.

We currently lack the data and ability to conclusively test these hypotheses. However, we hope that as the physiological basis for larval settlement becomes better understood the ability to distinguish among them will someday be available. We believe that our data indicate that some hypotheses are unlikely explanations for the initiation of aggregations of Hydroides dianthus, but we cannot currently reject any of them. Given our current data, we feel that the learning and the error-variance hypotheses are particularly unlikely to account for both the similarity and consistency of settlement patterns among larvae previously exposed to varying combinations of the experimental substrata. An examination of a number of obvious life-history correlates and larval feeding regimes suggests that decreased substratum-specificity is not associated with environmental factors, maternal state or larval energetic state (Toonen \& Pawlik 2001a, this issue). We have also undertaken a selection and cross-breeding experiment to examine the heritability of larval settlement preference, and we have found that the estimate of heritability for larval settlement on biofilm is unexpectedly high (Toonen \& Pawlik in press). The most likely explanations for the pattern of nongregarious settlement among the larvae of this gregarious tube worm appear currently to be either developmental constraint or polymorphic settlement response, especially given that we have found the proportion of founders in a given clutch to be a highly heritable trait (Toonen \& Pawlik in press). Further research into differential settlement of the larvae of gregarious species is likely to provide greater understanding of the processes governing the initiation and persistence of monospecific aggregations of nonclonal marine invertebrates.

Acknowledgements. We thank S. G. 'Master of the pump' Bullard, D. J. Mense, D. C. Swearingen III and, especially, A.A. Henrikson, for their assistance and helpful comments on both this project and earlier versions of the manuscript. Many helpful comments were also provided by L. Borghesi, S. Gilman, R. Grosberg, M. Hart, J. Lewis, P. Marko, E. Pearson, J. Stachowicz and the anonymous reviewers. D. E. Leone of General Dynamics graciously provided manuscript copies of 
his work, cited herein. Important statistical advice and assistance was provided by V. Starczak, D. Carlon, S. Gilman and D. Thiede, for which we are grateful. This research was supported by an Office of Naval Research grant (N00014-92-J1144) and an NSF Presidential Young Investigator Award (OCE-9158065) to J.R.P., and a Sir James Lougheed Alberta Heritage Scholarship and a Natural Sciences and Engineering Research Council of Canada (NSERC) post-graduate scholarship to R.J.T. Contribution number 259 to UNCW's Center for Marine Science Research.

\section{LITERATURE CITED}

Beckmann M, Harder T, Qian PY (1999) Induction of larval attachment and metamorphosis in the serpulid polychaete Hydroides elegans by dissolved free amino acids: mode of action in laboratory bioassays. Mar Ecol Prog Ser 190: 167-178

Bryan PJ, Qian PY, Kreider JL, Chia FS (1997) Induction of larval settlement and metamorphosis by pharmacological and conspecific associated compounds in the serpulid polychaete Hydroides elegans. Mar Ecol Prog Ser 146: 81-90

Bryan PJ, Kreider JL, Qian PY (1998) Settlement of the serpulid polychaete Hydroides elegans (Haswell) on the arborescent bryozoan Bugula neritina (L.): evidence of a chemically mediated relationship. J Exp Mar Biol Ecol 220:171-190

Burke RD (1986) Phermones and the gregarious settlement of marine invertebrate larvae. Bull Mar Sci 39:323-331

Carpizo-Ituarte E, Hadfield MG (1998) Stimulation of metamorphosis in the polychaete Hydroides elegans Haswell (Serpulidae). Biol Bull (Woods Hole) 194:14-24

Chia FS, Rice ME (eds) (1978) Settlement and metamorphosis of marine invertebrate larvae. Elsevier Publishing, New York

Crisp DJ (1974) Factors influencing the settlement of marine invertebrate larvae. In: Grant PT, Mackie AM (eds) Chemoreception in marine organisms. Academic Press, New York, p 177-265

Crisp DJ (1984) Overview of research on marine invertebrate larvae, 1940-1980. In: Costlow JD, Tipper RC (eds) Marine biodeterioration: an interdisciplinary study. Naval Institute Press, Annapolis, MD, p 103-126

Fenteany G, Morse DE (1993) Specific inhibitors of protein synthesis do not block RNA synthesis or settlement in larvae of a marine gastropod mollusk Haliotis rufescens. Biol Bull (Woods Hole) 184:6-14

Grosberg RK (1981) Competitive ability influences habitat choice in marine invertebrates. Nature (Lond) 290: 700-702

Guillard RRL (1975) Culture of phytoplankton for feeding marine invertebrates. In: Smith WL, Chanley MH (eds) Culture of marine invertebrate animals. Plenum Press, New York, p 29-60

Harder T, Qian PY (1999) Induction of larval attachment and metamorphosis in the serpulid polychaete Hydroides elegans by dissolved free amino acids: isolation and identification. Mar Ecol Prog Ser 179:259-271

Hartman O (1969) Atlas of the sedentariate polychaetous annelids from California. Allan Hancock Foundation, University of Southern California, Los Angeles

Holm ER (1990) Attachment behaviour in the barnacle Balanus amphitrite amphitrite (Darwin): genetic and environmental effects. J Exp Mar Biol Ecol 135:85-98

Knight-Jones EW (1951) Gregariousness and some other aspects of the setting behaviour of Spirorbis. J Mar Biol Assoc UK 30:201-222

Knight-Jones EW (1953) Laboratory experiments on gregariousness during setting in Balanus balanoides and other barnacles. J Exp Biol 30:584-599

Lau SCK, Qian PY (1997) Phlorotannins and related compounds as larval settlement inhibitors of the tube-building polychaete Hydroides elegans. Mar Ecol Prog Ser 159: 219-227

Leone DE (1970) The maturation of Hydroides dianthus. Biol Bull (Woods Hole) 138:306-315

Mackay TFC, Doyle RW (1978) An ecological genetic analysis of the settling behaviour of a marine polychaete. I. Probability of settlement and gregarious behaviour. Heredity 40:1-12

Mullineaux LS, Garland ED (1993) Larval recruitment in response to manipulated field flows. Mar Biol 116:667-683

Okamoto K, Watanabe A, Sakata K, Watanabe N (1998) Chemical signals involved in larval metamorphosis in Hydroides ezoensis (Serpulidae: Polychaeta). Part 1. Induction of larval metamorphosis by extract of adult tube clumps. J Mar Biotechnol 6:7-10

Pawlik JR (1986) Chemical induction of larval settlement and metamorphosis in the reef-building tube worm Phragmatopoma californica (Sabellariidae: Polychaeta). Mar Biol 91:59-68

Pawlik JR (1990) Natural and artificial induction of metamorphosis of Phragmatopoma lapidosa californica (Polychaeta: Sabellariidae), with a critical look at the effects of bioactive compounds on marine invertebrate larvae. Bull Mar Sci 46:512-536

Pawlik JR (1992a) Chemical ecology of the settlement of benthic marine invertebrates. Oceanogr Mar Biol Annu Rev 30:273-335

Pawlik JR (1992b) Induction of marine invertebrate larval settlement: evidence for chemical cues. In: Paul VJ (ed) Explorations in chemical ecology: ecological roles of marine natural products. Cornell University Press, Ithaca, New York, USA and London, England, p 189-236

Pechenik JA (1990) Delayed metamorphosis by larvae of benthic marine invertebrates: does it occur? Is there a price to pay? Ophelia 32:63-94

Pechenik JA (1999) On the advantages and disadvantages of larval stages in benthic marine invertebrate life cycles. Mar Ecol Prog Ser 177:269-297

Pechenik JA, Qian PY (1998) Onset and maintenance of metamorphic competence in the marine polychaete Hydroides elegans Haswell in response to three chemical cues. J Exp Mar Biol Ecol 226:51-74

Rejmanek M, Leps J (1996) Negative associations can reveal interspecific competition and reversal of competitive hierarchies during succession. Oikos 76:161-168

Scheltema RS (1974) Biological interactions determining larval settlement of marine invertebrates. Thalassia Jugosl 10:263-269

Scheltema RS, Williams IP, Shaw MA, Loudon C (1981) Gregarious settlement by the larvae of Hydroides dianthus (Polychaeta: Serpulidae). Mar Ecol Prog Ser 5:69-74

Sokal RR, Rohlf FJ (1981) Biometry. The principles and practice of statistics in biological research, 2nd edn. WH Freeman \& Company, New York

Stachowicz JJ, Whitlatch RB, Osman RW (1999) Species diversity and invasion resistance in a marine ecosystem. Science 286:1577-1579

Strathmann MF (ed) (1987) Reproduction and development of marine invertebrates of the Northern Pacific coast data 
and methods for the study of eggs embryos and larvae. University of Washington Press, Seattle

Toonen RJ (1993) Environmental and heritable components of settlement behavior of Hydroides dianthus (Serpulidae: Polychaeta). University of North Carolina at Wilmington, Wilmington, NC

Toonen RJ, Pawlik JR (1994) Foundations of gregariousness. Nature 370:511-512

Toonen RJ, Pawlik JR (1996) Settlement of the tube worm Hydroides dianthus (Polychaeta: Serpulidae): cues for gregarious settlement. Mar Biol 126:725-733

Toonen RJ, Pawlik JR (2001a) Settlement of the gregarious tube worm Hydroides dianthus (Polychaeta: Serpulidae). II. Testing the desperate larva hypothesis. Mar Ecol Prog Ser 224: 115-131

Toonen RJ, Pawlik JR (2001b) Foundations of gregarious: a dispersal polymorphism among the larvae of a marine invertebrate. Evolution (in press)

Unabia CRC, Hadfield MG (1999) Role of bacteria in larval settlement and metamorphosis of the polychaete $\mathrm{Hyd}$ roides elegans. Mar Biol 133:55-64

Verrill AE (1873) Report upon the invertebrate animals of Vineyard Sound and adjacent waters, with an account of the physical characters of the region. In: Baird CSF (ed)

Editorial responsibility: Otto Kinne (Editor),

Oldendorf/Luhe, Germany
Report on the Condition of the Sea Fisheries of the South Coast of New England in 1871 and 1872, Part I. Commission of Fish and Fisheries USA, Washington, DC, p 295-778

Walters LJ, Hadfield MG, del Carmen KA (1997) The importance of larval choice and hydrodynamics in creating aggregations of Hydroides elegans (Polychaeta: Serpulidae). Invertebr Biol 116:102-114.

Watanabe N, Watanabe S, Ide J, Watanabe Y, Sakata K, Okamoto K (1998) Chemical signals involved in larval metamorphosis in Hydroides ezoensis (Serpulidae; Polychaeta). Part II. Isolation and identification of a new monoacyl glycerol from adult tube clumps as a metamorphosis-inducing substance. J Mar Biotech 6:11-15

Wilson DP (1953) The settlement of Ophelia bicornis Savigny larvae. J Mar Biol Assoc UK 32:209-233

Young CM (1989) Larval depletion by ascidians has little effect on settlement of epifauna. Mar Biol 102:481-489

Zuraw EA, Leone DE (1968) Laboratory culture of the tubeworm Hydroides (Eupomatus) dianthus Verril [sic] 1873. General Dynamics, Electric Boat Division, Groton, CT

Zuraw EA, Leone DE (1972) Development of a tubeworm bioassay to evaluate antifouling coatings. General Dynamics, Electric Boat Division, Groton, CT

Submitted: July 21, 2000, Accepted: January 15, 2001

Proofs received from author(s): November 23, 2001 